\title{
Features of the Jordanian Cultural Identity in the Islamic Education Books for the Two Phases of Primary and Secondary Education in Jordan
}

\author{
Khalid A. Alsoudi ${ }^{1, *}$ \\ ${ }^{1}$ Curriculum and Instruction Department, College of Educational Sciences, Tafila Technical University, Tafila - \\ Jordan \\ *Correspondence: Curriculum and Instruction Department, College of Educational Sciences, Tafila Technical \\ University, Tafila, Jordan. E-mail: Awess12@yahoo.com
}

Received: February 22, 2017

Accepted: March 2, 2017 Online Published: April 15, 2017

doi:10.5430/wje.v7n2p50

URL: https://doi.org/10.5430/wje.v7n2p50

\begin{abstract}
The study aimed to investigate the subjects relating to the features of Jordanian cultural identity in Islamic education books for secondary and basic stages in Jordan which are (23) books through analyzing their content. For achieving the goals of the study, the researcher prepared an analysis list included a number of sub-elements distributed on general domains. The validity was checked by specialists. The readability was $(87 \%)$. The results indicated that the total of frequencies relating to the features of Jordanian culture identity were (589). The most frequencies appeared in the domain of culture components (166) with ratio of (28.1\%), followed by the domain of national cooperation's with (113) frequencies and ratio of (19.1\%). The domain of Jordanian geography was (111) frequencies and ratio of $(19 \%)$, then the domain of history and genesis with (109) frequencies and ratio of (18.5\%). the domain of current Jordanian role comes after with (54) frequencies and ratio of (92\%). The least domain was the Hashemite leadership with (36) frequencies and ratio of (6.1\%). Most of frequencies were in the $10^{\text {th }}$ grade book with (178) frequencies and ratio of (30.2\%). The least frequencies were in the $8^{\text {th }}$ grade book with (7) ) frequencies and ratio of (1.2\%). The study recommends that extra research and practice should be done benefiting from the analysis list used in this study when planning and setting up Islamic education books. The study suggested that other studies should be conducted relating to features of Jordanian cultural identity in curricula and books.
\end{abstract}

Keywords: cultural identity; Islamic education; basic instruction stage; secondary instruction stage

\section{Introduction}

The educational content is one of the most important textbook components, it organizes knowledge, skills and values set in a particular way that helps achieve the planned objectives. Its content is sincere when it translates the objectives of the curriculum, realistic and true in displaying concepts, appropriate for learners, expresses aspirations of communities and their aspirations and hopes of the emerging generations. It reflects the reality of these communities and ails of events, and crises these communities are going through (Hindi, 1987) school curriculum emerged from society, and it reflects the culture of the community in all its elements (religious beliefs, customs, traditions, patterns of thinking and behavior and methods of education $\quad .$. ).

The social and cultural foundation is the most prominent foundation of Islamic education curricula in Jordan. Since the religion of Islam did not neglect the customs and traditions that were prevalent in the community, as the basis of the foundations on which we must preserve. as prophet Muhammad said, peace be upon him: "I was sent to complete good morals" (Narrated by Ahmad in Musnad 8729) for this, we find that culture as one of the basic foundations of society cannot be disregarded in determining priorities and establishing its institutions in accordance with the objectives and beliefs of the community.

Recent years have seen considerable interest in the studies which have addressed the issue of cultural identity and accounted for the interest of many researchers and intellectuals, and the thing that has increased the problems of identity case of flip-flops Arab society between the call to different identities, Sometimes the call to Arab identity, and at other times to the Islamic identity, or national identities (Kamel, W.D.). 
Regional identities are the product of a social and cultural history in general, and represent an integrated relationship that covers a wide range of classification and theorization. it gives people the sense that they are linked together with a link that sometimes exceeds classes, under the umbrella of the political entity which we call "home", which brings together all individuals who live by and it leads to strengthen the feeling of belonging to the idea of political, social and geographical entity of the nation, and thus stir feelings and emotions and feelings toward home (Tarrah, 2002).

Jordan cultural identity, like other identities, mainly involves gloss and symbolic, culture and collectively gives the individual a sense of belonging to the larger body, creating his pride, and this is an important function of national identity; to defend their land and their community and their overall development, as well as the satisfaction of the basic needs of its citizens along with the adoption of the principle justice among citizens. This concept is linked to the state that population are alike. The advantage of the cultural identity of Jordan as identity based on diversity is the pop identity of the social fabric of Jordanian society combination, the Jordanian society contains a blend of social groups that have contributed to the formation of cultural identity (Shtawi, 2010).

In the context of talking about the responsibility of forming the Jordanian cultural identity and the preservation of its features, there are methodological questions that must be raised, and these questions are related to (cultural identity, and the curriculum): What are the components of the Jordanian cultural identity? And what are the forms through which this identity is expressed? In contrast, what is the official national curriculum's ability to express their cultural identity and community components?

Here the role of curricula and textbooks comes to shore as one of the highlights of institutional procedures that emphasize clearly shows what the national identity is, and how it is formed? And whether or not it is able to understand what does national identity of community members means, and that imposes on researchers and scholars for Education analysis of these measures through which national identity becomes a normal issue as it exists in the collective mind of the people.

Curriculums are no longer viewed as a group of subjects learned by the learner in classrooms, but rather seen as a collection of experiences learned by the learner within the walls of the educational foundation and beyond, in order to develop his personality in all aspects, modern curriculums derived its objectives of the culture of community, and thus what the learner is receiving from the experiences and activities, are only values, customs and traditions which generally reflect the cultural identity of the community (Hayek, 2011).

The curriculum was only a mirror that reflects the elements of constituent cultural identity, and since the formal curriculum in Jordan is supervised by a subsidiary of the Jordanian State institution, it has become necessary to become an echo of the voice of the community, that reflects the wishes, requirements, needs and problems, that paints a national picture, which is the emergence of religion, language, history and heritage of the material and intellectual achievements of Arab and Islamic nations. Cultural content is a shield that protects students from expatriate cultural currents, and would also set a ground for an education that is capable of maintaining and marketing a Jordanian national identity without hiding from the heritage of this identity.

In this context, the Islamic education plays a key role in the upbringing of the individuals and elevating their morals and souls, as well as modifying their behavior and directing them to the ways of goodness, providing legislation and beliefs, and playing a major role in social cohesion and value perseverance.

It is stated in the Arab Human Development Report (2004) that it is necessary to emphasize the need to resist seeking to cultural hegemony by Western movements, basing it on cultural advances. In the shadow of the "globalization"that the world is facing, which aims at adding pressure on local identities, Islamic education curricula must reconsider the components of the culture identity in the local communities, in a manner that qualifies this identity to be recognized in the national scene. Jordan was not immune to the targeting of the general features of its cultural identity of a humanitarian, Arab and Islamic Hashemite implications, especially since it is located on the largest line of confrontation with Israel, and that the sources of threat to this identity increased after the so-called Arab Spring, particularly those resulting from the presence of refugees from neighboring countries.

\section{The Problem of the Study}

Based on the above, the researcher believes that the Jordanian cultural ID photo looks dim, the researcher observed through his experience as a teacher of Islamic education as well as a supervisor for the material for a long time, and adhesion in the educational field as a researcher and supervisor of the formation of Islamic education curricula, that the students are trying to detach themselves from the Jordanian identity through different practices in language, dress, food and social values in general. The researcher attributes such practices to the nature of the curriculum, 
especially the Study of Islamic education. This is consistent with what was confirmed by the warrior (2008) that the cultural identity and values have not yet attained a straight-needed attention in the curriculum and teaching methods in educational institutions.

Since the general education (basic and secondary phases) is a broad-based educational institution in the Arab countries in general and Jordan in particular, the curriculum of Islamic education must highlight the cultural aspects through including these aspects in the educational content. Thus, the researcher conducted this study to detect features of the Jordanian cultural identity in the books of Islamic education for the two phases of primary and secondary education in Jordan.

\section{Question of the Study}

This study tried to answer the following question: What are the features of the Jordanian cultural identity in the books of Islamic education for the two phases of primary and secondary education in Jordan?

\section{The Importance of Studying}

The importance of the study is as follows:

1. The nature of the age group covered by the research analysis, primary and secondary education are of the most important stages of life in which the learner is subjected to the growth of physical, mental and emotional being; which makes the maintaining and strengthening of his national affiliation the key responsibility for the curricula received.

2. This study comes in response to calls by many educators and thinkers of the need to preserve cultural identity in the era of globalization and openness to the cultures of the world, and assuring the importance of implanting Islamic cultural values and principles enshrined in our heritage, and claim that the curriculum plays a major role in this area.

3. The importance of the study lies in being the only study at the level of Jordan - to the knowledge of the researcher - which tries to detect the dimensions of cultural identity in the books of Islamic education, the thing that helps in revealing areas of strength and weakness in the content of these books.

4. The importance of the study rises from the fact that it is a continuation of previous studies, such as the study (Al-ashiri 2002) which showed the existence of a cultural weakness in the content of books which will reflect negatively on the cultural construction of the learners.

\section{Terminology of Study}

There are a number of terms in the present study, which must be defined procedurally, which are as follows:

- Identity: defined as a psycho-social concept that refers to how to recognize a community or group of the same, and how to differentiate them from others (al-Hiti, 2001).

- Culture: Tyler defines the term in (Rashwan, 2003) as: All, which includes beliefs, laws and custom, art, morality and all the other capabilities and habits that is earned by human. Kilpatrick (1956) defines culture as everything that is created by a human hand and mind of things and aspects of the social environment, that is, everything human invented or discovered which had a role in the social process.

- Cultural Identity: the researcher adopts in this study the following definition as a definition of a procedural cultural identity: it is features and characteristics of human beings that he provides to others to define his patriotism through many indicators related to clothing or foods and dialects, customs and traditions (Muneer, 2002).

- Islamic education: courses presented for students in an integrated and comprehensive picture, such as the Holy Koran and Hadith, doctrine, biography (of the prophet) and ethics. These courses focused on the student and how to contribute in deepening his ties with God and his own as well as his people and everything that surrounds him in an Islamic perspective proper.

\section{Limits of the Study}

The limits of this research are confined within the following parameters:

- Objective limits: The study is limited to the substantive limits on the educational role of the Islamic Education Textbooks which are included in the features of the Jordanian cultural identity. 
- Spatial limits: Focus will be on the Hashemite Kingdom of Jordan through the books of Islamic education in the stages of public education.

- Epochal limits: This study will be conducted on prescribed books by the Ministry of Education and taught in the academic year 2013/2014 AD books.

\subsection{Previous Studies}

There are many educational studies in general, which tried to study a variety of cultural aspects, one of these studies done by Al-ashiri (2002) a study that aimed to assess the cultural aspects in the books of social material for the second cycle of primary education in the Kingdom of Bahrain, the fourth, fifth and sixth grades, for the academic year 2001-2002. The researcher used the content analysis method, and the number of pages that have been analyzed in the study sample (581) the results showed the existence of a cultural failure in the content of books of social studies for the second cycle of primary education; the study also showed that the axis of cultural aspects were characterized as random and lacked balance and regularity.

Khwaiter (2007) conducted a study focusing on the contribution of the governmental public high school in the city of Riyadh in rooting Islamic cultural identity among the students from the viewpoint of the teachers. The study sample of teachers reached (350) teacher, and the results showed that the government public high school for girls in Riyadh is doing its part in the origination of the Islamic cultural identity through the parameters above more than (curriculum and school activities), where the focus on teachers and their role in the origination of the Islamic cultural identity enjoyed the highest arithmetic average, which amounted to (3.71) point, the role of the curriculum followed, with an average of (3.63) point, followed by the role of school activities, amounted to an arithmetic mean of (3.00) point.

Babad (2007) also conducted the study aimed to reveal the cultural identity in the books of social studies phase upper basic education in Yemen through content analysis and point of view of teachers. The study concluded a number of results, most notably: the imbalance in the presentation of the dimensions of cultural identity in the books of social Studies of this phase, also, the lack of attention to some of the concepts and components of Arab cultural identity, such as the Islamic concept of moderation in Islam, and the importance of the unity of Yemen, and the concept of globalization....etc. The results also indicated that social studies books upper phase basic education - depending on teachers point of view- contribute to the strengthening of cultural identity, but to a lesser degree than the theoretical average of (3) degrees and by (60\%), where the arithmetic average (2.93) and by (58.6\%).

Also both Hammett and Bainbridge (2009) paper aimed to detect pluralism and cultural identity through the images included in the curricula and textbooks in the 'education colleges' in Canada, which is taught to teachers students before engaging in the teaching profession, which included a sample study of (6) picture Books, The study used interviews style. The results showed cultural diversity in these books, especially in educational situations inside the classroom.

Alsaila (2009) study sought to investigate the impact of the decision of the Islamic culture at the Sultan Qaboos University in promoting Islamic identity, the researcher used content analysis method and resulted in findings that the curriculum deepens the link between the student and God, and urges students to represent the values and principles of Islam in the political, economic and social life, and strengthen the autoimmune in the face of negative, vulnerable cultures hostile to his religion.

Savage, Hindle, Meyer, Hynds, Penetito, and Sleeter (2011) conducted a study that aimed to assess the impact of vocational development to instill cultural patterns in the teaching methods used by teachers at the secondary school students, the study relied on more than (400) classrooms, distributed to (32) public schools.

Interviews were also conducted with (214) students, and the researchers used multiple research methods, and the results showed that most teachers perform different cultural practices during their teaching time, as students showed multiple descriptions of the attention span performed by teachers to cultural patterns.

Khalaf's (2011) study tried to disclose the availability of Arab cultural identity of the Islamic elements in the books of social education at the primary level in the Kingdom of Saudi Arabia from the perspective of teachers. Study sample consisted of (130) teacher from schools of (Qurayyat) for the academic year (2010-2011 AD). The results showed that the average teachers estimates the study tool regarding the degree of availability of the Arab cultural identity of the Islamic elements in the books of social education at the primary level in Saudi Arabia amounted to (3.00) moderately, and the presence of statistically significant differences between the teachers' estimate was due to gender in favor of males, as well as Qualification variable in favor of higher qualification (post-graduate).And there are also significant differences between the teachers' estimates due to the variable of expertise for the benefit of 
people with many years of experience (10 and over).

Olaimat and Abu Sheikh (2013) ran a study which aimed to know the effect of Islamic culture courses at the Jordanian universities in the promotion of Islamic identity among students in light of the age of globalization requirements. Researchers used the content analysis method of the Islamic culture to be taught in Jordanian universities for the academic year 2010/2011. The style was a questionnaire composed by researchers from (25) paragraph describes the elements of Islamic culture in the era of globalization, the veracity and stability of the tool was ensured, and the partial idea was the unit analysis process, and it's monitoring frequencies and percentage was recorded in the book. One of the most important results that the following paragraphs enjoyed high repetition level, which were: that the book introduces the student to the sources of Islamic culture, the result came by (8.93\%), and that the book shows the risk of globalization on Islamic culture which came by $(8.63 \%)$, The paragraphs that received less duplicates are : clarify of the role of Muslim scholars in the culture of the Muslim nation which came by $(1.49 \%)$ and the paragraph that indicated the Islamization of the curriculum where it came by $(0.89 \%)$.

\subsection{General Comment on Previous Studies}

Previous studies focused on the question of educational values and cultural identity in a multi-curriculum (such as history, social studies books, Arabic, English, Physical Education) and focused on defining the concept of cultural identity and the challenges they face, and have been addressing these issues by using multiple research methods. While some of them have been through the points of view of the other teachers, including the analysis of textbooks. However, there is no study on the features of the Jordanian cultural identity in the Islamic education curricula in Jordan. Hence the importance of conducting such a study has been benefiting from these studies in the building of the background study to identify areas that could become in light of analysis, research and tools, as well as the discussion of the results.

\section{The Study Methodology and Procedures}

\subsection{Study Approach}

The researcher followed a descriptive and analytical approach based on content analysis (Content Analysis), which is a scientific research methods aimed at systematic and objective description of quantitative content of apparent substance of the communication materials (To'eima, 1987).

\subsection{The Study Population and Samples}

The study population and samples come from all the assessed books of Islamic Education of basic and secondary education in Jordan, which has been taught in the academic year 2013- 2014, the number of these books is (13) thirteen books, as shown in Table (1).

Table 1. Lessons and Parts Distribution and the Number of Pages in the Books of Islamic Education Primary and Secondary Phases

\begin{tabular}{cccccc}
\hline Phase & Class & Book name & $\begin{array}{c}\text { number } \\
\text { of parts }\end{array}$ & $\begin{array}{c}\text { number of } \\
\text { lessons }\end{array}$ & $\begin{array}{c}\text { number of } \\
\text { pages }\end{array}$ \\
\hline primary & First primary & Islamic education & 2 & 59 & 177 \\
& Second & Islamic education & 2 & 65 & 237 \\
& primary & & & & \\
& Third primary & Islamic education & 2 & 72 & 231 \\
& Fourth primary & Islamic education & 2 & 82 & 267 \\
& Fifth primary & Islamic education & 2 & 51 & 260 \\
& Sixth primary & Islamic education & 2 & 58 & 267 \\
& Seventh & Islamic education & 2 & 47 & 224 \\
& primary & & & & \\
& Eighth primary & Islamic education & 2 & 61 & 362 \\
& Ninth primary & Islamic education & 2 & 56 & 285 \\
Secondary & Tenth primary & Islamic education & 2 & 61 & 383 \\
& First level & Islamic culture & 1 & 33 & 165 \\
& Second level & Islamic culture & 1 & 30 & 158 \\
total & Third level & Islamic culture & 1 & 39 & 219 \\
& $\mathbf{1 3}$ & $\mathbf{1 3}$ & $\mathbf{2 3}$ & $\mathbf{7 1 4}$ & $\mathbf{3 2 3 5}$ \\
\hline
\end{tabular}




\subsection{The Study Instrument}

The researcher has built a rating (list analysis) related to common areas of Jordanian cultural identity, to be used as a criterion of analysis of Islamic education books, by conducting the following steps:

1. Seeking the views of a number of experienced and specialists in national education, social studies and Islamic religion, and those interested in the issues of the others, as well as methods of teaching Islamic education to identify general areas, and to identify sub-elements that fall under each area.

2. Deep access to some of the previous studies in the field of textbook content analysis; in order to benefit from its methodology in constructing list of analysis.

3. Review of educational literature on the subject of culture in general and cultural identity in particular.

\subsection{The Validity of the Study}

For the purpose of detecting the integrity of the tool that was developed to achieve the goal of the study, the general fields and sub-elements of the tool was presented to a panel of judges of (12) member from faculties of Jordanian universities members and administrators of Islamic education in the departments of Education; in order to achieve a high degree of confidence on the safety and accuracy of linguistic, scientific and technical point of view, everyone of them was asked to express an opinion as to whether the item was appropriate or inappropriate, and the amendment, which they deem appropriate. The majority of the arbitrators pointed to the need to highlight the sub-elements for each of the areas and the definition of its tool with illustrative examples. Based on their observations, the development of the final image was placed.

\subsection{The Unit of Analysis}

The researcher adopted the unity of the paragraph as a unit to analyze the content of Islamic books of education at both secondary and primary levels, which is one of the most widely used and useful units as it represents a phrase or statement that contains one of the ideas needed for analyzing the content. (Budd, Richard, 1976). This method was chosen by the researcher due to its accuracy and relevance, and thus includes other units of analysis that appear during the analysis process as part of it.

\subsection{Reliability of the Analysis}

The researcher adopted two methods to extract stability in this study, namely:

- The researcher agreement with himself over time, through reaching a very close results when using the content and procedures as well as the foundations of analysis and his steps when he carries two analysis separated by a short period of time a (month) for the same of sample $30 \%$ of the total number of pages of the entire study, represented in the Islamic books of basic and secondary stage.

- Agreement among analysts: Those two analysts in their fields agree to the subject of the study, and work independently to convergent results with the analysis results, when the same principles and steps and procedures for the same analysis and the same content are used for the aforementioned stability sample.

The researcher has used the (Azuroff \& Mayer, 1977) to calculate the reliability coefficient among analysts:

Namely: reliability coefficient $=\frac{\text { Number of agreed answers }}{\text { Number of agreed answers }+ \text { Number of non-agreed }} \times 100 \%$

The researcher calculates the reliability coefficient between the analysis in the first time and analyzed in a second time to the sample previously mentioned, and by using the previous equation and form analysis, the average of reliability coefficient amounted $(0.87 \%)$, and this percentage is not only adequate, but considered a high percentage to ensure the confidence of stable analysis.

\subsection{Statistical Treatment}

The study used frequencies, percentage analysis, also used (Azuroff \& Mayer) equation to calculate the percentage of agreement among analysts.

\section{Results and Discussion}

To facilitate the display the study results, it will be presented on two levels: 


\subsection{Level I: Results of Each Field Individually}

\subsubsection{Image of the Hashemite leadership}

Table 2. Features of Jordanian Cultural Identity in the Books of Islamic Education in the Area of the Hashemite Leadership Divided into Sub-Elements

\begin{tabular}{ccccccc}
\hline sub-Elements & $\begin{array}{c}\text { Current } \\
\text { leadership }\end{array}$ & $\begin{array}{c}\text { Former } \\
\text { leadership }\end{array}$ & $\begin{array}{c}\text { National } \\
\text { days }\end{array}$ & $\begin{array}{c}\text { Supporting } \\
\text { religious } \\
\text { texts }\end{array}$ & Total & Percentage \\
\hline first & - & - & 6 & - & 6 & $16.6 \%$ \\
second & - & - & 2 & - & 2 & $5.6 \%$ \\
third & - & - & 1 & - & 1 & $2.8 \%$ \\
fourth & - & - & 5 & - & 5 & $13.9 \%$ \\
fifth & 1 & - & 3 & - & 4 & $11.1 \%$ \\
sixth & 2 & - & 1 & - & 3 & $8.3 \%$ \\
seventh & 1 & - & 3 & - & 4 & $11.1 \%$ \\
eighth & - & - & - & - & - & - \\
ninth & 2 & 4 & - & 2 & 8 & $22.2 \%$ \\
tenth & - & - & - & - & - & - \\
Level 1 & - & - & - & - & - & - \\
Level 2 & 2 & - & - & - & 1 & $2.8 \%$ \\
Level 3 & 1 & 4 & 21 & 2 & 36 & $\% 100$ \\
Total & 9 & $11.1 \%$ & $58.3 \%$ & $5.6 \%$ & $\% 100$ & $100 \%$ \\
Percentage & $25 \%$ & & & & & \\
\hline
\end{tabular}

It is noted from Table (2) that the total frequencies that reflect the area of the Hashemite leadership are (36), distributed among the four sub-components: The most frequent were symbols and national events by (21) times, then the current leadership (9) times, followed by the former leadership (4) times, and finally supporting religious texts, (2) twice.

As it can be seen from the above table that the book of ninth grade received the highest frequency of the total frequencies that reflect the area of the Hashemite leadership, while no frequency was recorded in the book of Islamic education to the tenth grade, or the book of Islamic culture for the first level.

The researcher attributes the results of the high frequencies of symbols and national occasions to the focus of books on national meanings related to the Jordanian flag, the Royal Crown, and national events such as independence, and this concern is justified, since the love of homeland is installed within us, it is not surprising never that man loves his homeland, where he grew up as a child. What is linked to the home country also is his governors and his leadership, and the leadership of the Hashemite rooted to the house of prophecy, but the religious texts in support of the legitimate historical and religious leadership, has not received adequate reflection in the study sample books, perhaps to the belief of those in charge of these approaches to this matter is vested in the national books education or that these issue of Jordanian constants that do not require further confirmation.

\subsubsection{Jordan Genesis and History}

It is noted from Table (3) that the total frequencies that reflect the area of the emergence of Jordan and its history are (109) distributed among two subgroups: The most frequent is the Islamic civilization by (21) times, then ancient civilizations (4) times. As it can be seen from the above table that the Book of tenth grade received the highest repetition of the total frequencies that reflect the area of the Hashemite leadership of (100) times, while no repetition was recorded in the book of Islamic education for grades: I, II, III, IV, V, VII, VIII, IX, or the book of Islamic culture for the first level. 
Table 3. Features Jordanian Cultural Identity in the Books of Islamic Education on the Origins and History of Jordan Divided into Sub-Elements

\begin{tabular}{ccccc}
\hline sub- elements & Old civilizations & Tslamic civilization & Total & percentage \\
class & - & - & - & - \\
first & - & - & - & - \\
second & - & - & - & - \\
third & - & - & - & - \\
fourth & - & - & - & - \\
fifth & - & 1 & 1 & $0.9 \%$ \\
sixth & - & - & - & - \\
seventh & - & - & - & - \\
eights & - & 2 & 2 & $1.8 \%$ \\
Ninth & 3 & 97 & 100 & $91.7 \%$ \\
tenth & - & - & - & - \\
Level 1 & 1 & 2 & 3 & $2.8 \%$ \\
Level 2 & - & 3 & 3 & $2.8 \%$ \\
Level 3 & 4 & 105 & 109 & $100 \%$ \\
total & $3.7 \%$ & $96.3 \%$ & $\% 100$ & $100 \%$ \\
Percentage & & & & \\
\hline
\end{tabular}

The researcher attributes the result of Islamic civilization element for a higher frequencies in this area to focus their books on highlighting the Islamic face of the country, the cradle of civilization and the land of heavenly and place called God's messengers messages Almighty throughout history, Jordan housed thousands of Cram companions who were buried along the Jordan River, which is only commanded at the Medina spot. Jordan gates the Islamic conquest, and on Jordanian territory was some major historical battles, most notably Mutah ... .. and Yarmouk and Fahl. Land also witnessed many events such as the Abbasid and Fatimid advocacy, arbitration and others. It seems that the Islamic Education Textbooks are not paying attention to the ancient civilizations on the land of Jordan, except as may be home to martyrdom in a direct and explicit content of the educational context. However, the researcher noted by carrying out the analysis that the Book of tenth grade won the largest share of the display through the condenser of the Companions in Jordan; necessitating the need to distribute this content on the rest of the classes.

\subsubsection{Geographical Dimensions in Jordan}

It is noted from Table (4) that the total frequencies that reflect the area of Jordan Geography are (111), distributed among the five sub-components: The most frequent is nature and cities by (106) times, then the terrain (3) times, followed by a space and the border by (2) times, while no repetition in the field of resources was recorded. The environmental concerns, as it can be seen from the above table that the book of tenth grade received the highest repetition of the total frequencies that reflect the geographic area of Jordan, while no repetition was recorded in the book of Islamic education for first, second and fifth grades.

The researcher attributes the result of the element of cities in Jordan to get the highest frequencies in this area to the focus of books in highlighting the associated places, religious or historical events to the context of striking jurisprudential examples. This shows that Jordan cities and villages was the stage for many important events. Most Jordan regions witnessed an Islamist or historical event. It is natural that the elements of borders and terrain are low, as it comes not from the philosophy of Islamic Education Textbooks to sink learners in the issues of terrains and borders. However, these books failed to address environmental concerns directly, because even if these books mentioned these concerns in general, they did not give privacy to the environment of Jordan, no doubt that the separation between environmental issues and its relation to the pressing issues in the Jordanian environment may weaken the sense of belonging among the educated, the thing that would create a good citizen who preserves the environment and public property. 
Table 4. Features Jordanian Cultural Identity in the Books of Islamic Education Geographical Dimensions Distributed to Sub-Elements

\begin{tabular}{cccccccc}
\hline sub- elemen & $\begin{array}{c}\text { Space } \\
\text { and } \\
\text { boarders }\end{array}$ & Geography & $\begin{array}{c}\text { Nature } \\
\text { and } \\
\text { cities }\end{array}$ & Resources & $\begin{array}{c}\text { Environment } \\
\text { and concerns }\end{array}$ & Total & Percentage \\
\hline First & - & - & - & - & - & - & - \\
second & - & - & - & - & - & - & - \\
Third & - & - & 2 & - & - & 2 & $1.8 \%$ \\
Fourth & 1 & 1 & 1 & - & - & 3 & $2.7 \%$ \\
Fifth & - & - & - & - & - & - & - \\
Sixth & - & - & 7 & - & - & 7 & $3.6 \%$ \\
Seventh & - & - & 2 & - & - & 2 & $1.8 \%$ \\
Eighth & - & 1 & - & - & - & 1 & $0.9 \%$ \\
Ninth & - & 1 & 2 & - & - & 3 & $2.7 \%$ \\
Tenth & 1 & - & 77 & - & - & 78 & $70.2 \%$ \\
Level 1 & - & - & 1 & - & - & 1 & $0.9 \%$ \\
Level 2 & - & - & 3 & - & - & 3 & $2.7 \%$ \\
Level 3 & - & - & 11 & - & - & 11 & $10 \%$ \\
Total & 2 & 3 & 106 & - & - & 111 & $100 \%$ \\
Percentage & $1.8 \%$ & $2.7 \%$ & $95.5 \%$ & - & - & $\% 100$ & $\% 100$ \\
\hline
\end{tabular}

Table 5. Features of Jordanian Cultural Identity in the Books of Islamic Education for National Institutions Distributed to Sub-Elements

\begin{tabular}{|c|c|c|c|c|c|c|c|c|c|c|}
\hline Elements & 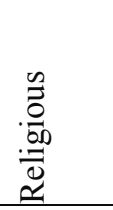 & 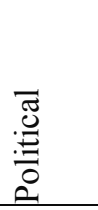 & 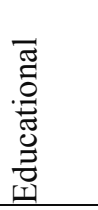 & $\begin{array}{l}\overline{\sigma \pi} \\
\overline{8} \\
\mathscr{n}\end{array}$ & 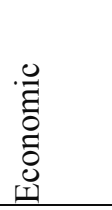 & 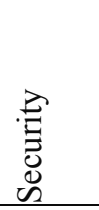 & 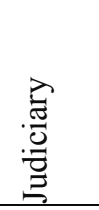 & 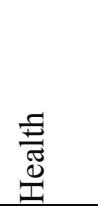 & Total & Percentage \\
\hline first & 5 & - & 20 & - & - & - & - & - & 25 & $22.1 \%$ \\
\hline second & - & - & 2 & - & - & - & - & - & 2 & $1.8 \%$ \\
\hline third & 4 & - & 7 & - & 1 & - & - & - & 12 & $10.6 \%$ \\
\hline fourth & 11 & - & 2 & - & 9 & - & - & - & 22 & $19.4 \%$ \\
\hline fifth & 4 & - & - & - & - & 4 & - & - & 8 & $7 \%$ \\
\hline sixth & 3 & 1 & 1 & 1 & 3 & - & - & 1 & 10 & $9 \%$ \\
\hline seventh & 2 & - & 2 & 2 & - & 1 & - & - & 7 & $6.2 \%$ \\
\hline eight & 2 & - & - & - & - & 1 & - & - & 3 & $2.6 \%$ \\
\hline ninth & 12 & & 1 & 2 & 2 & - & 1 & - & 18 & $16 \%$ \\
\hline tenth & - & - & - & - & - & - & - & - & - & - \\
\hline Level 1 & 2 & - & - & - & - & - & - & - & 2 & $1,8 \%$ \\
\hline Level 2 & 1 & - & - & 1 & - & - & 1 & - & 3 & $2.6 \%$ \\
\hline Level 3 & - & - & - & 1 & - & - & - & - & 1 & $0.9 \%$ \\
\hline total & 46 & 1 & 35 & 7 & 15 & 6 & 2 & 1 & 113 & $100 \%$ \\
\hline percentage & $40.7 \%$ & $0.9 \%$ & $31 \%$ & $6.2 \%$ & $13.2 \%$ & $5.3 \%$ & $1.8 \%$ & $0.9 \%$ & $100 \%$ & $100 \%$ \\
\hline
\end{tabular}


It is noted from Table (5) that the total frequencies that reflect the area of national institutions are(113) distributed among the eight sub-components: The most frequent is religious institutions by (46) times, educational institutions came in the second place with (35) times, In third place economic institutions (15) visits, and in the fourth place is social institutions by (7) times, ranked fifth security institutions by (6) times, and ranked sixth economic institutions by (2) times, the last rank went for political institutions and health institutions with the rate of one repetition (1) each. As it can be seen from the above table that the basic first-grade book received the highest repetition of the total frequencies that reflect the area of national institutions, while no repetition was recorded in the book of Islamic education to the tenth primary grade.

The researcher attributes the result of racist and religious institutions, educational institutions to get the highest frequencies in this area, to the fact that the curriculum are more attached to the religious establishment and the educational institution, due to the role of the two institutions in promoting the values that the textbook seeks to highlight. The book's focus on highlighting the religious role of national institutions enhances the conviction of learners to the importance of these institutions in education, especially the mosque, where the mosque enjoys a superpower status, since it is the first place that launched the Islamic call and raised the prophet's noble companions. This result is consistent with Alshaila study (2009), which resulted in the findings that decision, deepens the link among a student with his God and his religion, and urges students to represent the values and principles of Islam in the political, economic and social life.

\subsubsection{Cultural Components of Jordanian Society}

It is noted from Table (6) that the total frequencies that express the field of the cultural components of Jordanian society are (166), distributed among the three sub-components: The most frequent is cultural generalities by (131) times, then the cultural variables came in second place by (28) visits, in the third place lies the cultural specificities by (7) times. As it can be seen from the above table that the book of basic sixth grade received the highest repetition of the total frequencies that expressed the field of cultural components of the Jordanian society, while no repetition was recorded in the book of Islamic education to the tenth primary grade.

Table 6. Features of Jordanian Cultural Identity in the Books of Islamic Education and Cultural Components of Jordanian Society Divided into Sub-Elements

\begin{tabular}{cccccc}
\hline Sub Elements & Generalities & Particularities & Variables & Total & percentage \\
Class & & & & & \\
first & 12 & - & - & 12 & $7.2 \%$ \\
second & 10 & - & - & 10 & $6 \%$ \\
third & 12 & - & - & 12 & $7.2 \%$ \\
fourth & 7 & - & - & 7 & $4.3 \%$ \\
fifth & 19 & - & - & 19 & $11.4 \%$ \\
sixth & 32 & - & - & 32 & $19.2 \%$ \\
seventh & 12 & 2 & - & 14 & $8.4 \%$ \\
eight & 1 & - & - & 1 & $0.6 \%$ \\
ninth & 6 & 1 & - & 7 & $4.3 \%$ \\
tenth & - & - & - & - & - \\
Level 1 & 3 & 2 & - & 5 & $3 \%$ \\
Level 2 & 14 & - & 5 & 19 & $11.4 \%$ \\
Level 3 & 3 & 2 & 23 & 28 & $17 \%$ \\
total & 131 & 7 & 28 & 166 & $100 \%$ \\
percentage & $79 \%$ & $4.2 \%$ & $16.8 \%$ & $100 \%$ & $100 \%$ \\
\hline
\end{tabular}


In this area, the keenness of the authors of books to be in harmony with the lifestyle prevailing in Jordanian society in various physical and moral forms seems clear. Jordanian culture such as values, customs and traditions, joys and sorrows, foods and drinks, uniforms, clothes, titles and nicknames, images revealing building model, has all been highlighted. Focusing on generalities confirm a job in unifying the curriculum and co-smelting sons of the nation in general lines which unite them. This result is consistent with Batayneh study (2009) which showed that the English language books at the secondary level in Jordan are based mainly on the local culture of the students. But differs with the Hayek study (2011), the results of which showed a consensus of all the students on the low level of educational values embodied in the colleges of physical education curricula of four universities. On the other hand, Islamic education books showed part of the cultural features that have not yet settled, such as: contemporary issues, innovations and challenges... and the display was part of that in the context of the religious edict. This result is consistent with Alshaili (2009) study, which findings showed that the curriculum strengthens autoimmune of the student against the negative hostile cultures to his religion.

Books analysis process has also revealed the pale emergence of cultural peculiarities, there seems to be a fear that haunted the authors of textbooks. And this concern pointed to the lack of prejudice to these idiosyncrasies that may impede the process of cooperation and social cohesion. However, the researcher sees no prejudice to the specificities, but exposure in what can be shown a cause to be respected by others. For example, in the context of talking about the co-existence, people of Jordan's experience in Madaba, where co-exist Muslims and Christians was supposed to be mentioned, where they meet on national lines, social and cultural authentic. The thing that reinforces this trend is that the Jordanian people are one fabric and what brings them together is more than what divides them. This result agrees with Baebad study (2007), which showed a lack of balance in the presentation of the cultural identity dimensions in the books of social studies in this stage.

\subsubsection{Contemporary Role of Jordan}

It is noted from Table (7) that the total frequencies that expresses the field of cultural components of Jordanian society were (45), distributed among the three sub-components: The most frequent is Islamic dimension by (42) times, the Arab dimension came in second place by (10) visits, and in third place there is the human dimension by (2) times.

Table 7. Features of Jordanian Cultural Identity in the Books of Islamic Education for Contemporary Role of Jordan Divided into Sub-Areas

\begin{tabular}{cccccc}
\hline Sub-Elements & $\begin{array}{c}\text { Arab } \\
\text { dimension }\end{array}$ & $\begin{array}{c}\text { Islamic } \\
\text { dimension }\end{array}$ & $\begin{array}{c}\text { Human } \\
\text { Dimension }\end{array}$ & Total & Percentage \\
class & - & - & - & - & - \\
first & - & - & - & - & - \\
second & - & - & - & - & - \\
third & - & - & - & - & - \\
fourth & 1 & 1 & - & 2 & $3.7 \%$ \\
fifth & - & - & - & 7 & $13 \%$ \\
sixth & - & - & - & - & - \\
seventh & 1 & - & - & 2 & $3.7 \%$ \\
eight & - & - & - & - & - \\
ninth & - & 1 & - & - & - \\
tenth & - & 5 & - & 1 & $1.8 \%$ \\
Level 1 & 2 & 42 & 2 & 7 & $13 \%$ \\
Level 2 & 6 & $77.8 \%$ & $3.7 \%$ & $100 \%$ & $100 \%$ \\
Level 3 & 10 & & & 54 & $100 \%$ \\
total & $18.5 \%$ & &
\end{tabular}


As can be seen from the above table that the book of Islamic culture for the third level received the highest repetition of the total frequencies that expresses the field of contemporary Jordan's role, while no repetition was recorded in the book of Islamic education for grades: First, second, third, seventh, ninth and tenth.

The researcher attributes results for the Islamic dimension of the highest occurrences in this area to focus of books to highlight the efforts of Jordan (leadership, people and institutions) on the Islamic level. There is no doubt that Jordan's local, Arab and international role cannot be denied, however, the focus on the Islamic religious dimension role is what has to be supported and focused on in the books of Islamic education. This dimension mainly appears through Jordan's role in the defense of the Palestinian issue, which has been historically associated with Jordan since the establishment of the Emirate of Transjordan in 1921, in Palestine, and since then, the Palestinian issue remained since 1948 the first title in the Jordanian political agenda at the regional and international levels. Jordan has taken care of the affairs of Jerusalem, there is a committee for the reconstruction of Al-Aqsa mosque and the Dome of the rock, and the Royal Commission for Jerusalem Affairs, as well as the Jordanian Hashemite Fund for the reconstruction of the Al Aqsa mosque and the Dome of the rock and Islamic holy sites, as well as what has been carried out by the Ministry of Awqaf and Islamic Affairs and the Department of Chief Justice of care and shouldering institutions and their citizens expenses.

This result differs with Baebad study (2007), which showed a lack of attention to some of the concepts and components of Arab cultural identity in the Muslim dimension. Analyst books also noted the importance of the Amman Message in highlighting the bright image of Islam in the entire world and to clarify the purpose of the message of Islam to achieve goodness and compassion for all people, and preached the principles of Islam-Semitism and its values, which are made throughout history, which created strong and a great cohesive nation, the basis of which is the unification of God and the faithful messenger, peace be upon him.

It also emphasizes that the call to God Almighty approach is based on kindness and gentleness and reject violence and cruelty in the orientation and expression, and that all forms of extremism and terrorism, which are intended to malpractice and the use of unethical destruction of urbanization and seize the cities, are all far from Islam which is based on moderation and tolerance.

The Arab dimension came in the second place. Keeping in mind that both dimensions overlap and share lots of things, the issue of Palestine is an Islamic Arab issue, and Amman message aimed at the Arab, Islamic and international community. This result agrees with the study of Khalaf (2011), the results of which showed that the average teachers' estimates study tool on the degree of availability of the Arab cultural identity of Islamic elements in the books of social education at the primary level in Saudi Arabia amounted to (3.00) moderately.

The researcher noticed some failure in embedding the Islamic Education Textbooks with the global role on the humanitarian level played by Jordan, with the presence of too many examples, most notably the peacekeepers.

8.2 Level II: Results of all questions of the study, based on the five general areas that underscore the image of the other in the sample study books, and Table (7) illustrates this.

It is noted from the collective table (8) that all occurrences of the public sphere regarding the cultural identity of Jordan in the books of Islamic education to the basic education level in Jordan were distributed to (589) frequency. The results of table (8) can be illustrated as follows:

1. The field of "cultural component" scored the highest repetition reaching (166) frequency, by (28.1\%)

2. The second place: the area of national institutions (113) frequency, by (19.1\%)

3. Third place: the area of Jordan Geography (111) frequency, by (19\%)

4. Fourth place: the field of upbringing and history (109) frequency, by (18.5\%)

5. Fifth place: the field of "contemporary role of Jordan" (54) frequency, by (9.2\%)

6. Sixth place: the area of the Hashemite leadership (36) frequency, by (6.1\%)

The results of the study are overall consistent with the Khwaiter study (2007), which referred to the role of school courses to deepen cultural identity. It should be noted that many of the inclusions in the basic stage came through the visual content, the thing that underlines the importance of visual organizations (photos, graphics and table formats) to deepen the concepts of cultural identity of Jordan, as the Islamic Education Textbooks highlighted many of these features through photos and maps. 
Table 8. Results Summary of Islamic Education Textbooks Analysis in Terms of Features of the Jordanian Cultural Identity Spread Over Fields

\begin{tabular}{|c|c|c|c|c|c|c|c|c|}
\hline the field & $\begin{array}{l}\text { Hashem-ite } \\
\text { leadership }\end{array}$ & $\begin{array}{l}\text { Upbringing } \\
\text { and history }\end{array}$ & $\begin{array}{l}\text { Jordanian } \\
\text { geography }\end{array}$ & $\begin{array}{l}\text { National } \\
\text { institution }\end{array}$ & $\begin{array}{l}\text { Cultural } \\
\text { component }\end{array}$ & $\begin{array}{l}\text { Contemporary } \\
\text { role of Jordan }\end{array}$ & Total & Percentage \\
\hline first & 6 & - & - & 25 & 12 & - & 43 & $7.3 \%$ \\
\hline second & 2 & - & - & 2 & 10 & - & 14 & $2.4 \%$ \\
\hline third & 1 & - & 2 & 12 & 12 & - & 27 & $4.6 \%$ \\
\hline fourth & 6 & - & 3 & 22 & 7 & - & 37 & $6.3 \%$ \\
\hline fifth & 4 & - & - & 8 & 19 & 2 & 33 & $5.6 \%$ \\
\hline sixth & 3 & 1 & 7 & 10 & 32 & 7 & 60 & $10.1 \%$ \\
\hline seventh & 4 & - & 2 & 7 & 14 & - & 27 & $4.5 \%$ \\
\hline eight & - & - & 1 & 3 & 1 & 2 & 7 & $1.2 \%$ \\
\hline ninth & 8 & 2 & 3 & 18 & 7 & - & 38 & $6.4 \%$ \\
\hline tenth & - & 100 & 78 & - & - & - & 178 & $30.2 \%$ \\
\hline Level 1 & - & - & 1 & 2 & 5 & 1 & 9 & $1.5 \%$ \\
\hline Level 2 & 2 & 3 & 3 & 3 & 19 & 7 & 37 & $6.3 \%$ \\
\hline Level 3 & 1 & 3 & 11 & 1 & 28 & 35 & 79 & $13.4 \%$ \\
\hline total & 36 & 109 & 111 & 113 & 166 & 54 & 589 & $100 \%$ \\
\hline percentage & $6.1 \%$ & $18.5 \%$ & $19 \%$ & $19.1 \%$ & $28.1 \%$ & $9.2 \%$ & $100 \%$ & $100 \%$ \\
\hline
\end{tabular}

This study is also consistent with a study of (Hammett, \& Bainbridge, 2009), which results showed the existence of cultural diversity in the embedded photos in the curricula and school textbooks.

The advent of cultural components field in the first place can be explained as being due to the fact that the essence of the cultural act lies in the emergence of dominant cultural elements in the life of society. There is a correlation between identity and culture as they are two sides of the same coin, and this confirms the authors of Islamic education keenness on linking students with their social reality, and not become detached from direct relevance to the community as well as its needs, problems, concerns and patterns of life.

The advent of the field of leadership in last place can be explained as being due to the belief that Islamic Education Textbooks concepts are focused on clearer and deeper in the books of Social Studies and specifically the National Education books. Also because such topics take up much space in the official and non-official media, as well as other space in extracurricular activities in school life (school radio, celebrations ...), not to mention that these issues might be touched by teachers while teaching through classroom discussions. A study has shown (Savage, Hindle, Meyer, Hynds, Penetito, \& Sleeter, 2011) that most teachers perform different cultural practices during their classes.

It has been observed from the collective table No (8) that the majority of occurrences came in a book of tenth grade (178) frequency by (30.2\%), while the least was of the eighth basic grade (7) frequencies by (1.2\%). This refers to a state of imbalance in the distribution of concepts related to the features of the cultural identity in all textbooks within a deliberate and well thought plan.

\section{Recommendations}

In light of the previous findings the researcher recommends:

- Benefit from the list of analysis used in this study when planning or composing books of Islamic education; to include the content of Islamic Education Textbooks basic concepts related to cultural identity of Jordan.

- Pay more attention to the elements of the cultural identity of Jordan, such as: supporting texts for the legitimacy of leadership religiously and historically, and worries that threaten the stability of the Jordanian environment, and exemplify the reality of the Jordanian society on cultural peculiarities, and highlight the contemporary role of Jordan in humanitarian and global dimension. 
- Enrich the fields related to the Jordanian cultural identity included in the books of Islamic education through educational films, trips and extracurricular activities.

- Emphasize the composers of Islamic education curricula to show the Jordanian cultural identity concepts in the content of Islamic education textbooks in an orderly and balanced manner among fields.

- Conduct an exploratory field study on the extent of awareness of Islamic education teachers of the issues related to features of cultural identity of Jordan, and the disclosure of teacher's role in strengthening the cultural identity and instilling it in the minds of the disciples.

- Conduct studies to learn about dimensions of cultural of the other at different learning levels.

- Conduct studies seeking to identify the role of the media and civil society organizations in the promotion of the dimension of cultural identity.

\section{References}

Al-Esheri, H. (2002). Evaluating Cultural Dimensions in the Books of Social Material for the Second Level of Primary Education. Unpublished Master's Thesis, Education Faculty, University Of Bahrain.

Al-harbi, I. (2008). The Embedded Educational Values in the Books of Mathematics in the Kingdom Of Saudi Arabia. The Twentieth Scientific Conference, The Egyptian's Association For Curriculum And Teaching Methods, Cairo, Egypt, P 274-243.

Al-Hayek, S. (2011). Cultural Identity in the Curriculum of Sport Education Faculties in Jordanian Universities at the Globalization Era. Studies, Educational Sciences, 4, 1470-1484.

Al-Khuayter, S. (2007). The Role of High School in Originating the Islamic Cultural Identity for School Girls. A Survey Conducted In Reyad. Unpublished Master's Thesis. The Islamic University of Imam Muhammed Bin Saed, Reyad, Kingdom Of Saudi Arabia.

Al-Shaeily, A. (2009). The Islamic Textbook and Its Impact on Enhancing the Islamic Identity. Retrieved from: www.shaeily.com.abhath

Al-Tarrah, A. (2002). Nations and National Identities: The Obstacle Of The Link Between People And Nations. Published Paper In The Book Of "National Identities And Universal Community And Media". Dar Al Nahda Al Arabeya, Beirut.

Arab Human Development Report (2004). The United Nations Development Programme. The Regional Office, Amman-Jordan.

Baebad, S. (2007). A study which intended to uncover the cultural identity in the books of social studies in the higher level of primary school in Yemen by analyzing its contents and teacher's perspectives. Unpublished master's thesis, university of Hadramout, Yemen.

Budd, R., \& others (1976). Content Analysis of Communication. New York, Wiely.

Hammett, R., \& Bainbridge, J. (2009). Pre-Service Teachers Explore Cultural Identity and Ideology through Picture Books. Literacy, 43(3), 152-159. https://doi.org/10.1111/j.1741-4369.2009.00522.x

Hindi, S. (1987). Studies in Curriculums and General Methods. Jordan, Amman, the Association of Printing Labors Co.

Kamel, N. (D.T). (1993). Theoretical Frame to the Study of National Identity. Unpublished Paper. Amman, Jordan Academy of Arabic.

Khalf, R. (2011). The Availability Of The Elements Of Arab Islamic Cultural Identity In Books Of Social Education For Primary Level In Saudi Arabia From The Perspective Of Teachers. Unpublished Master's Thesis, Al-Yarmouk University, Jordan.

Muneer, G. (2002). Features and Indications of National Identity, National Identity, Local Community and Media. Beirut. Dar Al Nahda Al Arabeya,

Nasser, I. (1983). Education And The Community Culture: Community Education. Beirut, Dar Al-Furqan, Al Resalah Institution.

Olemat, A., \& Abu Sheik, A. (2013). Suggested Curriculum For Islamic Education To Enhance Islamic Identity For Jordanian Universities Students In Light Of Globalization Requirements. University Of Azhar Magazin, Gaza. 
Series Of Humaterian Science, 1, 142-119.

Savage, C., Hindle, R., Meyer, L. H., Hynds, A., Penetito, W., \& Sleeter, C. E. (2011). Culturally responsive pedagogies in the classroom: indigenous student experiences across the curriculum. Asia-Pacific Journal of Teacher Education, 39(3), 183-198. https://doi.org/10.1080/1359866X.2011.588311

Shtawi, M. (2010). Social Integration and the Development of the Jordanian National Identity. Unpublished Worksheet, Amman.

Toeimah, R. (1987). Analyzing Content of Humetarien Science: Definition and Usage Principles. Cairo, Dar El-Fekr Al-Arabi. 